\title{
PENINGKATAN KETERAMPILAN MEMBACA INTENSIF UNTUK MENEMUKAN GAGASAN UTAMA DENGAN MENGGUNAKAN METODE COOPERATIVE INTEGRATED READING AND COMPOSITIO DAN TEKNIK REPETISI PADA SISWA KELAS VII SMP NEGERI 1 SURUH TRENGGALEK
}

\author{
SITI MUAWANAH \\ SMPN 1 Suruh Trenggalek \\ e-mail: sitimuamanah10@gmail.com
}

\begin{abstract}
ABSTRAK
Berdasarkan hasil analisis data dapat diketahui bahwa keterampilan membaca intensif untuk menemukan gagasan utama setelah mengikuti pembelajaran dengan metode Cooperative Integrated Reading and Composition dan teknik Repetisi terbukti mengalami peningkatan. Hasil tes keterampilan membaca intensif untuk menemukan gagasan utama pada prasiklus dapat diketahui bahwa nilai rata-rata sebesar 59,5 atau sebesar 59,47\% dan pada siklus I diperoleh nilai rata-rata sebesar 66,81 atau sebesar $66,81 \%$. Hal ini berarti terjadi peningkatan sebesar 7,34\%. Pada siklus II diperoleh nilai rata-rata kelas tes membaca intensif untuk menemukan gagasan utama sebesar 75,05 atau sebesar 75,05\%. Atas dasar hal tersebut dapat diketahui peningkatan dari siklus I ke siklus II sebesar 8,24\%. Hal ini juga dapat diketahui adanya peningkatan sebesar $15,58 \%$ dari prasiklus ke siklus II. Perubahan tingkah laku siswa dapat dilihat secara jelas pada saat pembelajaran. Berdasarkan hasil data nontes siklus I, masih tampak perilaku negatif siswa saat pembelajaran berlangsung. Pada siklus II perilaku negatif siswa semakin berkurang dan perilaku positif siswa semakin bertambah.

Kata kunci: membaca intensif, gagasan utama, metode Cooperative Integrated Reading and Composition, teknik Repetisi.
\end{abstract}

\section{PENDAHULUAN}

Membaca adalah salah satu dari empat keterampilan berbahasa (atau language arts, language skills). Kurikulum di sekolah biasanya mencakup empat segi, yaitu keterampilan menyimak/mendengarkan, keterampilan berbicara, keterampilan membaca, dan keterampilan menulis (Tarigan 1987:1). Membaca sebagai salah satu kemampuan dasar perlu mendapat perhatian khusus dari semua pihak, baik sekolah sebagai penyelenggara pendidikan, masyarakat, maupun pemerintah. Hal ini disebabkan oleh kenyataan bahwa membaca merupakan kunci untuk memperoleh informasi lengkap dan menyeluruh dari berbagai disiplin ilmu. Untuk itu, perkembangan ilmu pengetahuan, teknologi, dan seni dapat diikuti dan dikuasai salah satunya dengan keterampilan membaca. Keterampilan membaca juga sangat penting bagi seseorang untuk memperoleh kesenangan atau hiburan yang sehat dari membaca, misalnya dengan membaca karya sastra.

Tarigan (1987:7) berpendapat bahwa membaca adalah suatu proses yang dilakukan serta dipergunakan oleh pembicara untuk memperoleh pesan, yang hendak disampaikan oleh penulis melalui media kata-kata/bahasa tulis. Proses ini dilakukan serta dipergunakan agar kelompok kata yang merupakan suatu kesatuan akan terlihat dalam suatu pandangan sekilas, dan agar makna kata-kata secara individual akan dapat diketahui. Kalau hal ini tidak dipenuhi, maka pesan yang tersurat dan yang tersirat tidak akan tertangkap atau dipahami dan proses membaca itu tidak terlaksana dengan baik Hodgson (dalam Tarigan 1960:43-44).

Keberhasilan seseorang di dalam membaca ditentukan oleh beberapa faktor. Faktorfaktor yang menentukan keberhasilan membaca itu antara lain (1) keterampilan mengidentifikasi bunyi atau korespondensi simbol; (2) penggunaan pengetahuan tata bahasa untuk memperoleh arti; (3) penggunaan teknik yang berbeda untuk tujuan yang berbeda; (4) kemampuan menghubungkan isi teks dengan pengetahuan latar belakang; dan (5) kemampuan mengidentifikasi tujuan retorikal dan fungsional kalimat-kalimat individual (bagian-bagian teks). Hardjasudjana (dalam Susanip 2006:1-2). 
Dalam materi pengajaran bahasa, terutama keterampilan membaca, diharapkan siswa memperoleh informasi dan memberikan tanggapan dengan tepat ukuran dari bacaan dan mampu mendalami, menghayati, serta menarik manfaat dari bacaan. Pengajaran membaca dewasa ini perlu diartikan sebagai sarana pengembangan bagi pengembangan keterampilan berbahasa lainnya. Corak membaca untuk kurikulum 2006 sesuai dengan berbagai ranah bahasa harus lebih diwarnai kegiatan berbahasa. Selanjutnya mereka dapat berkomunikasi dengan gagasan yang dituangkan dalam bahasa tulis. Demikian pula dengan pengajaran membaca di SMP, siswa harus lebih banyak dihadapkan dengan berbagai ragam bacaan. Berbagai keterampilan membaca harus dilatihkan kepada siswa agar kepemilikan keterampilan itu bermanfaat dalam kehidupan sehari-hari.

Dalam Kurikulum Tingkat Satuan Pendidikan (KTSP) SMP kelas VII terdapat standar kompetensi pada aspek membaca, yaitu memahami wacana tulis melalui kegiatan membaca intensif dan membaca memindai. Kompetensi dasar yang diambil adalah menemukan gagasan utama dalam teks yang dibaca. Untuk mencapai standar kompetensi dan kompetensi dasar tersebut, kegiatan sekolah harus lebih dari sekadar kegiatan pengajaran. Kegiatan sekolah adalah kegiatan pembelajaran. Siswa belajar, saling belajar, bukan hanya dari guru melainkan dari teman-teman sekelas, sesekolah, serta dari sumber belajar lain. Pendekatan pembelajaran yang digunakan oleh guru juga harus dapat mengantarkan siswa pada pembelajaran yang bermakna.

Pengajaran Bahasa dan Sastra Indonesia dengan materi yang disajikan secara sistematis sesuai dengan kegiatan di masyarakat mengharapkan siswa agar mampu menyerap materi tentang berbagai hal. Selain itu, siswa juga harus mampu mencari sumber, menyimpulkan, dan menyaring materi pembelajaran. Dalam keterampilan berbahasa khususnya membaca, siswa dituntut untuk menyerap isi pembelajaran yang sebanyak-banyaknya sekaligus dapat berlatih mengenai bahan pelajaran Bahasa Indonesia.

Seorang siswa memang seharusnya sudah memiliki keterampilan membaca karena keterampilan membaca dapat dijadikan sebagai modal utama dalam proses belajar mengajar. Berbekal keterampilan membaca, siswa akan lebih mudah dalam proses belajar. Kelancaran dan kesuksesan prestasi akan diperoleh siswa dengan mudah serta akan memperoleh pengetahuan dan meningkatkan pola berpikir kritis.

Nurhadi (2005:123) menyatakan hal yang harus diperhatikan oleh seorang pembaca dalam memperlancar proses membaca harus memiliki modal, antara lain

1) pengetahuan dan pengalaman;

2) kemampuan berbahasa (kebahasaan);

3) pengetahuan tentang teknik membaca; dan

4) tujuan membaca.

Dalam menghadapi kenyataan tersebut pengajaran membaca di SMP hendaknya memperhatikan hal-hal seperti perkembangan program membaca, keadaan murid- murid di SMP, metode, serta bahan yang meliputi keterampilan-keterampilan yang perlu dikuasai, bidang isi, dan pelayanan perpustakaan. Karena itu, dalam rangka tercapainya kualitas pendidikan semaksimal mungkin sesuai dengan yang diharapkan harus kita laksanakan, khususnya melalui kemampuan keterampilan membaca (Tarigan, dkk 1990:171-172).

Pada umumnya pengajaran membaca terutama membaca intensif untuk menemukan gagasan utama pada siswa SMP masih dirasakan kurang. Hal ini disebabkan oleh kenyataan bahwa terlalu banyaknya kompetensi dasar yang terdapat di dalam kurikulum. Di samping hal di atas, faktor siswa juga mempunyai pengaruh dalam melakukan membaca intensif. Ini diperlukan keahlian siswa dalam mengikuti kegiatan belajar mengajar.

Penelitian ini akan dilaksanakan di SMP, yaitu akan membahas tentang kemampuan membaca intensif untuk menemukan gagasan utama dalam setiap paragraf dan kemampuan menyimpulkan isi dari teks bacaan dalam bentuk ringkasan pada siswa kelas VII SMP Negeri 1 Suruh Trenggalek yang masih kurang maksimal. Kemampuan siswa dalam memahami wacana tulis untuk menemukan gagasan utama pada teks bacaan masih sering keliru atau 
kurang cermat. Siswa cenderung kurang memahami letak gagasan utama dengan tidak tepat. Mereka sering menganggap bahwa gagasan utama hanya terdapat di awal atau akhir paragraf. Padahal, gagasan utama pada sebuah paragraf dapat berada di awal pragaraf, di tengah paragraf, di akhir paragraf, di awal dan di akhir paragraf, atau keseluruhan isi paragraf merupakan gagasan utama sebuah paragraf.

Adapun kemampuan siswa dalam menyimpulkan isi teks bacaan dalam bentuk ringkasan masih sering tidak logis, tidak urut, dan tidak sesuai dengan isi bacaan. Hal ini disebabkan oleh kenyataan bahwa siswa kurang mampu memahami isi bacaan dengan baik, sehingga motif membaca hanyalah sekadar kesenangan atau hiburan sementara. Siswa membaca tetapi apa yang telah dibaca tidak mereka pahami makna yang terkandung dalam teks bacaan tersebut.

Keterampilan membaca merupakan sesuatu yang berkesinambungan, sama halnya dengan siswa kelas VII SMP Negeri 1 Suruh Trenggalekada yang cepat dalam membaca, ada yang lambat, dan ada yang masih mempunyai kebiasaan buruk dalam membaca. Beragam kemampuan siswa tersebut akan dapat diseragamkan dengan adanya penelititan ini meskipun tidak seragam secara mutlak paling tidak siswa kelas VII SMP Negeri 1 Suruh Trenggaleksudah dapat meningkatkan keterampilan membaca intensif untuk menemukan gagasan utama dengan metode Cooperative Integrated Reading and Composition dan teknik Repetisi.

Hal yang menyebabkan kemampuan membaca intensif untuk menemukan gagasan utama dan menyimpulkan isi teks bacaan dalam bentuk ringkasan pada siswa kelas VIIkurang maksimal salah satunya adalah kondisi siswa dalam menerima pelajaran belum efektif. Dalam menerima pelajaran, kelas belum dikondisikan senyaman mungkin menuju proses pembelajaran yang serius namun nyaman. Pengelolaan kelas dan pengondisian siswa merupakan kunci utama dalam pencapaian keberhasilan proses pembelajaran. Pembelajaran kurang efektif dapat terjadi karena penyampaian materi pelajaran kurang menarik atau teknik mengajar yang monoton. Peran guru sangat penting dalam hal ini. Guru harus dapat menciptakan suasana yang menyenangkan agar proses pentransferan materi dapat diterima dengan baik oleh siswa. Untuk itu, metode Cooperative Integrated Reading and Composition dan teknik Repetisi yang diterapkan dalam pengajaran membaca intensif untuk menemukan gagasan utama sangat tepat.

Metode Cooperative Integrated Reading and Composition bertujuan untuk mengetahui gagasan utama pada tiap-tiap paragraf yang ada pada suatu teks bacaan karena metode ini melibatkan tim-tim kooperatif ke dalam rangkaian kegiatan bersama, termasuk saling membacakan satu dengan yang lainnya, menulis tanggapan terhadap suatu wacana, saling membuatkan ikhtisar berlatih pengajaran, serta perbendarahaan kata. Cooperative Integrated Reading and Composition adalah bagian metode kooperatif yang komprehensif atau dan lengkap untuk pengajaran membaca dan menulis kelas tinggi (Suyatno 2004:35).

Pengajaran kooperatif muncul dari konsep bahwa siswa akan lebih mudah menemukan dan memahami konsep yang sulit jika mereka saling berdiskusi dengan temannya. Dalam pengajaran kooperatif siswa dikelompokkan ke dalam kelompok-kelompok kecil yang mempunyai kemampuan akademik yang heterogen, di sini siswa dituntut untuk mampu bekerja sama dengan kelompok lain, berlatih bertanggung jawab, dan dapat menghargai pendapat orang lain. Adapun teknik Repetisi dipilih karena membaca intensif dalam memahami wacana tulis untuk menemukan gagasan utama pada teks bacaan digunakan pembaca dengan mengulang bacaan yang sudah dibaca. Hal tersebut dilakukan dengan tujuan untuk memperkuat informasi yang telah dihafal, sehingga mudah untuk diingat kembali. Yang direpetisi bukanlah semua bagian bacaan, melainkan bagian tertentu atau hal tertentu saja, yaitu bagian yang perlu dihafal lagi, informasi penting, kata kunci, dan hal-hal lain yang dianggap penting.

Dalam pengajaran keterampilan membaca intensif untuk menemukan gagasan utama, siswa diharapkan mampu memahami teks bacaan yang ada. Pemberian latihan di kelas merupakan salah satu faktor yang dapat meningkatkan kemampuan siswa dalam membaca intensif untuk menemukan gagasan utama pada teks bacaan secara tepat. Selain kegiatan 
membaca intensif untuk menemukan gagasan utama dengan menggunakan metode Cooperative Integrated Reading and Composition dan teknik Repetisi, siswa diharapkan pula dapat menyimpulkan kembali secara ringkas isi teks bacaan secara tepat.

Dalam pengajaran membaca intensif sebuah teks bacaan masalah yang ditemukan yaitu (a) motivasi dan kemampuan membaca yang kurang; (b) model pengajaran yang monoton (konvensional); dan (c) pelatihan secara terstruktur yang kurang dilakukan oleh siswa kelas VII SMP Negeri 1 Suruh Trenggalek.

Dalam proses belajar mengajar, ketepatan membaca siswa sangat diperlukan untuk bisa menemukan gagasan utama dalam sebuah teks bacaan. Permasalahan lain yaitu penilaian yang dilakukan guru di kelas kurang menggunakan cara dan alat yang bervariasi. Penilaian diarahkan pada penguasaan bahan yang disajikan dalam bentuk tes objektif. Hal ini disebabkan oleh beberapa hal sebagai berikut (a) Siswa kurang latihan dalam membaca secara benar; (b) bahan kurang menarik, tidak sesuai dengan keinginan siswa, sehingga motif membaca hanya sekadar pengisi waktu luang; (c) guru kurang memberikan latihan pada siswa dalam kegiatan membaca; (d) guru kurang memiliki pengetahuan dan kemahiran tentang berbagai metode dan teknik penilaian, sehingga kurang tepat memilih dan melaksanakan dengan tepat metode dan teknik penilaian yang ada; serta (e) guru kurang mengerti perkembangan hasil belajar siswa dalam kegiatan membaca intensif untuk menemukan gagasan utama.

Berdasarkan latar belakang di atas, peneliti bermaksud mengadakan penelitian guna meningkatkan kemampuan membaca siswa kelas VII SMP Negeri 1 Suruh Trenggalekdalam pengajaran membaca intensif untuk menemukan gagasan utama dengan menggunakan metode Cooperative Integrated Reading and Composition dan teknik Repetisi. Hal tersebut bertujuan untuk mencapai kompetensi dasar kurikulum dalam mengidentifikasi gagasan utama dari sebuah teks bacaan.

\section{METODE PENELITIAN}

Metode yang digunakan oleh peneliti dalam penelitian ini adalah Penelitian Tindakan Kelas (PTK). Seperti yang didefinisikan oleh Suyanto (dalam Subyantoro 2007:6) bahwa PTK sebagai tindakan tertentu agar dapat memperbaiki dan atau meningkatkan praktik-praktik pembelajaran di kelas secara profesional. Subjek penelitian ini adalah keterampilan membaca intensif untuk menemukan gagasan utama pada siswa kelas VII SMP Negeri 1 Suruh Trenggalek. Jumlah siswa ada 43 orang yang terdiri atas 24 puteri dan 19 putera. Kelas VII SMP Negeri 1 Suruh Trenggalek ada 5 kelas dengan jumlah siswa seluruhnya sebanyak 215 siswa. Alasan dijadikannya kelas VII SMP Negeri 1 Suruh Trenggalek sebagai subjek penelitian adalah karena peneliti ingin mengetahui seberapa banyak siswa yang mengalami kesulitan membaca intensif untuk menemukan gagasan utama dalam pengajaran Bahasa dan Sastra Indonesia, khususnya dalam kompetensi dasar membaca intensif untuk menemukan gagasan utama. Berikut skema bagan penelitian tindakan kelas. 


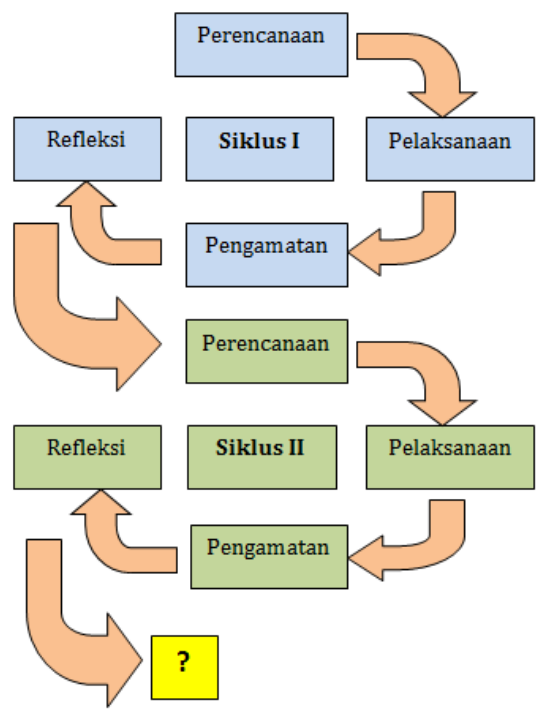

\section{Gambar 1. Skema Bagan Penelitian Tindakan Kelas}

\section{HASIL DAN PEMBAHASAN}

\section{Hasil Penelitian}

Hasil penelitian tindakan kelas ini diambil dari tes awal, tindakan kelas pada siklus I, dan tindakan kelas pada siklus II. Hasil tes awal berupa keterampilan membaca intensif untuk menemukan gagasan utama pada siswa sebelum dilakukan tindakan kelas siklus I. Hasil tes tindakan kelas siklus I dan siklus II berupa keterampilan siswa dalam membaca intensif untuk menemukan gagasan utama dengan menggunakan metode Cooperative Integrated Reading and Composition dan teknik Repetisi, sedangkan hasil nontes berupa observasi, jurnal siswa dan jurnal guru, wawancara, dan dokumentasi foto.

\section{Kondisi Awal}

Kondisi awal penelitian tindakan kelas adalah kondisi siswa sebelum dilaksanakannya pengajaran membaca intensif untuk menemukan gagasan utama dengan menggunakan metode Cooperative Integrated Reading and Composition dan teknik Repetisi. Untuk mengetahui keterampilan membaca intensif dilakukan tes awal (prasiklus) sebelum dilaksanakannya pengajaran membaca intensif untuk menemukan gagasan utama dengan menggunakan metode Cooperative Integrated Reading and Composition dan teknik Repetisi untuk mengetahui keadaan awal keterampilan membaca intensif siswa kelas VII SMP Negeri 1 Suruh Trenggalek. Soal yang digunakan berupa tes tertulis, yaitu tes menemukan gagasan utama dan tes menyimpulkan isi teks bacaan dalam bentuk ringkasan. Di bawah ini adalah tabel hasil tes awal keterampilan membaca intensif untuk menemukan gagasan utama sebelum dilaksanakan penelitian lebih lanjut.

Tabel 1 Hasil Tes Prasiklus Keterampilan Membaca Intensif untuk Menemukan Gagasan Utama

\begin{tabular}{|c|c|c|c|c|c|c|}
\hline No & $\begin{array}{c}\text { Rentang } \\
\text { Nilai }\end{array}$ & Kategori & Frekuensi & Bobot & Persentase & $\begin{array}{c}\text { Skor } \\
\text { Rata-rata }\end{array}$ \\
\hline 1 & $85-100$ & Sangat Baik & - & - & - & \\
\hline 2 & $75-84$ & Baik & 2 & 153 & $5 \%$ & $=59,5$ \\
\hline 3 & $65-74$ & Cukup & 14 & 941 & $33 \%$ & Kategori \\
\hline 4 & $55-64$ & Kurang & 16 & 958 & $37 \%$ & Kurang \\
\hline
\end{tabular}




\begin{tabular}{|l|l|l|c|c|c|}
\hline 5 & $0-54$ & Sangat Kurang & 11 & 505 & $25 \%$ \\
\hline \multicolumn{2}{|c|}{ Jumlah } & 43 & 2557 & $100 \%$ \\
\hline
\end{tabular}

Dari tabel 1 tersebut diketahui bahwa rata-rata skor siswa yang dicapai pada tes awal sebesar 59,5. Siswa yang memperoleh kategori sangat baik dengan rentang nilai 85-100 tidak ada. Siswa yang memperoleh kategori baik dengan rentang nilai 75-84 sebanyak 5\% atau 2 siswa dari jumlah keseluruhan siswa. Siswa yang memperoleh kategori cukup dengan rentang nilai 65-74 sebanyak 33\% atau 14 siswa dari jumlah keseluruhan siswa. Adapun kategori kurang dengan rentang nilai 55-64 sebanyak 37\% atau 16 siswa dari jumlah keseluruhan. Dan siswa yang memperoleh kategori sangat kurang dengan rentang nilai 0-54 sebanyak $25 \%$ atau 11 siswa dari jumlah keseluruhan. Dari hasil tes awal (prasiklus) tersebut disimpulkan bahwa kondisi awal keterampilan membaca intensif untuk menemukan gagasan utama pada siswa masih berada dalam kategori kurang karena rata-rata nilai yang diperoleh sebesar 59,5 yang berada dalam rentang nilai 55-64.

Selain itu, nilai yang diperoleh siswa belum mencapai target yang ditetapkan, yaitu 70 yang masuk dalam kategori cukup karena masih terdapat 27 siswa atau sebesar $62 \%$ yang memperoleh nilai di bawah 70. Keadaan dan kondisi tersebut menjadi dasar dilakukannya pembelajaran lebih lanjut tentang pengajaran membaca intensif untuk menemukan gagasan utama dengan menggunakan strategi yang berbeda, yaitu dengan menggunakan metode Cooperative Integrated Reading and Composition dan teknik Repetisi.

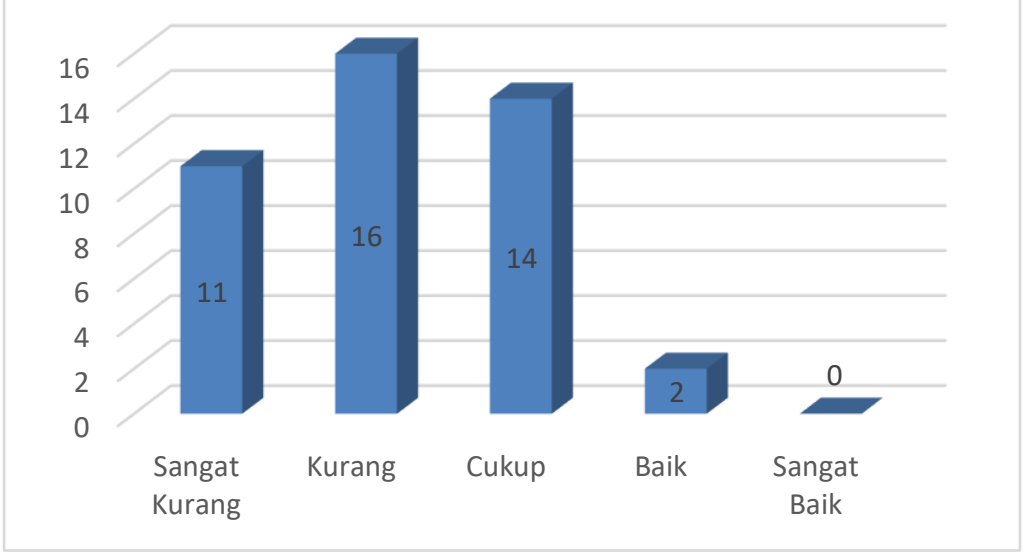

Gambar 1. Grafik Hasil Tes pra Siklus

Dari grafik 1 tersebut diketahui bahwa mayoritas nilai rata-rata siswa masih berada pada kategori kurang, yaitu 59,5 yang berada antara rentang nilai 55-64 dicapai 16 siswa atau sebesar $37 \%$. Pada kategori baik dengan rentang nilai 75-84 dicapai 2 siswa atau sebesar 5\%, kategori cukup dengan rentang nilai 65-74 dicapai 14 siswa atau sebesar 33\%, dan kategori sangat kurang dengan rentang nilai 0-54 dicapai 11 siswa atau sebesar 25\%. Adapun siswa yang memperoleh nilai dengan kategori sangat baik dengan rentang nilai 85-100 tidak ada.

Berdasarkan hasil tes tersebut dapat disimpulkan bahwa nilai rata-rata keterampilan membaca intensif yang diperoleh siswa sebesar 59,5. Hasil tersebut masih termasuk dalam kategori kurang, sehingga perlu ditingkatkan. Oleh karena itu, berdasarkan data yang diperoleh pada prasiklus ini menjadi dasar untuk perlu dilakukannya perbaikan melalui penelitian tindakan kelas membaca intensif untuk menemukan gagasan utama dengan menggunakan metode Cooperative Integrated Reading and Composition dan teknik Repetisi.

\section{Siklus I}

Pelaksanaan pengajaran membaca intensif untuk menemukan gagasan utama dengan menggunakan metode Cooperative Integrated Reading and Composition dan teknik Repetisi pada siklus I terdiri atas data tes dan data nontes dengan hasil penelitian sebagai berikut. 


\section{1) Hasil Tes Siklus I}

Dalam tes siklus I tindakan yang dilakukan di awal proses pembelajaran adalah guru terlebih dahulu melakukan apersepsi dengan menyapa dan menanyakan keadaan siswa, sehingga tercipta suasana yang kondusif dan komunikatif dalam kelas. Selanjutnya guru menanyakan tujuan dan manfaat pembelajaran yang akan dilaksanakan pada hari itu secara singkat.

Memasuki kegiatan inti, siswa memperhatikan penjelasan dari guru tentang materi yang akan dibahas, yaitu tentang membaca intensif untuk menemukan gagasan utama dengan menggunakan metode Cooperative Integrated Reading and Composition dan teknik Repetisi. Siswa dibagi antara 4-5 siswa tiap kelompok, setelah itu siswa memperoleh teks bacaan yang berjudul "Pengembangan Iptek Tidak Bisa Liar " yang dibagikan oleh guru. Kemudian siswa disuruh membaca teks bacaan tersebut, siswa yang telah paham saling mengajari dan bertukar pikiran dengan teman lainnya dalam satu kelompok. Siswa berdiskusi dalam kelompok masingmasing untuk menemukan gagasan utama dalam teks bacaan yang telah disediakan. Perwakilan dari setiap kelompok untuk mempresentasikan hasil diskusi kelompoknya. Kelompok yang lain menanggapi kelompok yang maju. Setelah itu, guru memberikan penguatan terhadap hasil presentasi dan tanggapan siswa. Guru bersama siswa mengevaluasi hasil pembelajaran. Kemudian guru meminta siswa untuk menyimpulkan isi dari teks bacaan dalam bentuk ringkasan yang dilakukan secara individu. Selanjutnya siswa bersama guru melakukan refleksi terhadap proses pengajaran membaca intensif untuk menemukan gagasan utama pada hari itu. Jadi, dalam siklus I tes dilakukan pada saat menemukan gagasan utama dan tes menyimpulkan isi teks bacaan dalam bentuk ringkasan. Hasil tes tersebut selanjutnya dikumpulkan pada guru dan kemudian hasil tes tersebut dikoreksi dan dinilai oleh guru untuk mengetahui hasil keterampilan membaca intensif siswa.

Hasil tes membaca intensif untuk menemukan gagasan utama dengan menggunakan metode Cooperative Integrated Reading and Composition dan teknik Repetisi siklus I dapat dilihat pada tabel di bawah ini. Hasil masing-masing aspek dipaparkan sebagai berikut. Aspek Menemukan Gagasan Utama dalam Teks Bacaan

Tabel 2. Aspek Menemukan Gagasan Utama dalam Teks Bacaan

\begin{tabular}{|c|c|c|c|c|c|}
\hline No & \begin{tabular}{c|c} 
Rentang & Kategori \\
Nilai &
\end{tabular} & Frekuensi & Bobot & Persentase & $\begin{array}{c}\text { Skor } \\
\text { Rata-rata }\end{array}$ \\
\hline 1 & 90-100|Sangat Baik & - & - & - & \multirow{2}{*}{$\begin{array}{l}=67,97 \\
\text { Kategori }\end{array}$} \\
\hline 2 & 70-89Baik & 8 & 616 & $19 \%$ & \\
\hline 3 & 50-69 Cukup & 35 & 2307 & $81 \%$ & \multirow[t]{4}{*}{ Cukup } \\
\hline 4 & \begin{tabular}{l|l|} 
Kurang & Kurat \\
\end{tabular} & - & - & - & \\
\hline 5 & 10-29 Sangat Kurang & - & - & - & \\
\hline \multicolumn{2}{|r|}{ Jumlah } & 43 & 2923 & $100 \%$ & \\
\hline
\end{tabular}

Dari tabel 2 tersebut diketahui bahwa rata-rata nilai siswa dalam keterampilan membaca intensif aspek menemukan gagasan utama dengan menggunakan metode Cooperative Integrated Reading and Composition dan teknik Repetisi. Rata-rata skor siswa yang dicapai sebesar 67,97. Nilai rata-rata yang diperoleh siswa dalam tes tersebut termasuk dalam kategori cukup karena berada pada rentang nilai 50-69. Di mana siswa yang memperoleh nilai dengan kategori sangat baik dengan rentang nilai antara 90-100 tidak ada. Kategori baik dengan rentang nilai antara 70-89 diperoleh sebesar 19\% atau sebanyak 8 siswa dari jumlah keseluruhan siswa. Kategori cukup dengan rentang nilai antara 50-69 diperoleh sebesar 81\% atau sebanyak 35 siswa dari jumlah keseluruhan siswa. Adapun jumlah siswa yang memperoleh nilai kategori 
kurang dengan rentang nilai 30-49 dan kategori sangat kurang dengan rentang nilai 10-29 tidak ada.

\section{2) Observasi}

Pada siklus I ini, terdapat beberapa perilaku siswa yang terdeskripsi melalui kegiatan observasi. Selama proses kegiatan pengajaran membaca intensif untuk menemukan gagasan utama dengan menggunakan metode Cooperative Integrated Reading and Composition dan teknik Repetisi tidak semua siswa mengikuti proses pembelajaran dengan baik. Peneliti dapat memaklumi keadaan tersebut karena proses pembelajaran yang dilakukan peneliti merupakan sesuatu yang baru dan belum pernah diajarkan pada mereka sebelumnya, sehingga dibutuhkan proses untuk menyesuaikannya. Berikut adalah tabel data hasil observasi yang diperoleh peneliti.

Tabel 3. Hasil Observasi Siklus I

\begin{tabular}{|c|c|c|c|c|c|c|c|}
\hline \multirow[t]{2}{*}{ No } & \multirow[t]{2}{*}{ Aspek yang diamati } & \multicolumn{3}{|c|}{ Melakukan } & \multicolumn{3}{|c|}{$\begin{array}{c}\text { Tidak } \\
\text { Melakukan }\end{array}$} \\
\hline & & $\mathrm{F}$ & $\%$ & K & $\mathrm{F}$ & $\%$ & K \\
\hline 1 & $\begin{array}{l}\text { Siswa semangat dan antusias saat } \\
\text { mengikuti pengajaran keterampilan } \\
\text { membaca intensif }\end{array}$ & 23 & $53 \%$ & $\mathrm{C}$ & 20 & $47 \%$ & $\mathrm{C}$ \\
\hline 2 & $\begin{array}{l}\text { Siswa merespon positif terhadap } \\
\text { metode } \quad \text { Cooperative Integrated } \\
\text { Reading and Composition dan teknik } \\
\text { Repetisi yang digunakan oleh } \\
\text { guru }\end{array}$ & 23 & $53 \%$ & $\mathrm{C}$ & 20 & $47 \%$ & $\mathrm{C}$ \\
\hline 3 & $\begin{array}{l}\text { Siswa membaca intensif dengan } \\
\text { sikap yang baik }\end{array}$ & 21 & $49 \%$ & $\mathrm{C}$ & 22 & $51 \%$ & $\mathrm{C}$ \\
\hline 4 & Kerjasama dalam kelompok tinggi & 20 & $47 \%$ & $\mathrm{C}$ & 23 & $53 \%$ & $\mathrm{C}$ \\
\hline 5 & 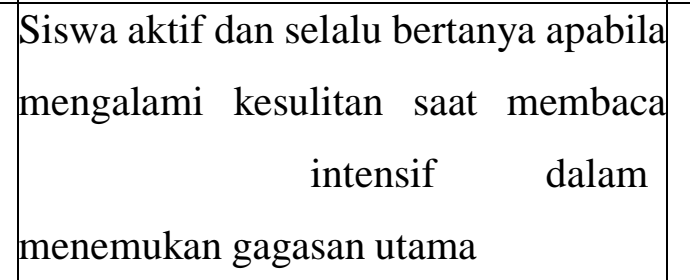 & 21 & $49 \%$ & $\mathrm{C}$ & 22 & $51 \%$ & $\mathrm{C}$ \\
\hline 6 & $\begin{array}{l}\text { Siswa memiliki sikap duduk dan } \\
\text { aktifitas yang baik }\end{array}$ & 19 & $44 \%$ & $\mathrm{C}$ & 24 & $56 \%$ & $\mathrm{C}$ \\
\hline 7 & $\begin{array}{l}\text { Siswa menerapkan metode } \\
\text { Cooperative } \\
\text { Composition dan teknik } \\
\text { Repetisi }\end{array}$ & 22 & $51 \%$ & $\mathrm{C}$ & 21 & $49 \%$ & $\mathrm{C}$ \\
\hline
\end{tabular}




\begin{tabular}{|l|l|c|c|c|c|c|c|}
\hline 8 & $\begin{array}{l}\text { Siswa mengerjakan tugas membaca } \\
\text { intensif teks bacaan }\end{array}$ & 43 & $100 \%$ & SB & 0 & $0 \%$ & SK \\
\hline Jumlah rata-rata & 192 & $56 \%$ & & 152 & $44 \%$ & \\
\hline
\end{tabular}

Berdasarkan tabel 3 tersebut dapat diketahui bahwa siswa yang semangat dan antusias saat mengikuti pengajaran keterampilan membaca intensif sebanyak 23 siswa atau 53\% , sedangkan sisanya sebesar 20 siswa atau $47 \%$ dari jumlah seluruh siswa kurang merespon pembelajaran yang berlangsung.

Sama halnya dengan metode Cooperative Integrated Reading and Composition dan teknik Repetisi yang digunakan oleh guru, yaitu siswa yang merespon positif terhadap metode dan teknik yang digunakan oleh guru sebanyak 23 siswa atau 53\%, sedangkan sisanya sebesar 20 siswa atau $47 \%$ dari jumlah seluruh siswa kurang merespon terhadap metode dan teknik yang digunakan oleh guru. Berdasarkan hasil dari observasi siklus I tersebut, dapat disimpulkan bahwa sebagian besar siswa kurang antusias dan kurang merespon pada saat pembelajaran berlangsung. Untuk itu, dibutuhkan solusi pemecahan masalah pada pertemuan atau siklus selanjutnya dalam mengatasi dan memperbaiki tingkah laku siswa yang cenderung ke arah negatif daripada ke arah yang positif, sehingga diharapkan pada siklus II akan lebih baik daripada siklus I.

\section{3) Refleksi Siklus I}

Setelah pelaksanaan tindakan siklus I, peneliti melakukan analisis terhadap hasil tes, hasil observasi, hasil jurnal, dan hasil wawancara yang telah dilakukan. Analisis ini bertujuan untuk mengetahui (1) kelebihan dan kekurangan metode dan teknik yang digunakan oleh guru dalam proses pembelajaran siklus I; (2) tindakan-tindakan yang dilakukan oleh siswa selama proses pembelajaran siklus I; dan (3) tindakan-tindakan yang dilakukan guru selama proses pembelajaran. Refleksi pada siklus I dilakukan untuk mengubah strategi pembelajaran pada siklus II.

Pengajaran membaca intensif untuk menemukan gagasan utama dengan menggunakan metode Cooperative Integrated Reading and Composition dan teknik Repetisi pada siklus I dapat diketahui bahwa metode dan teknik yang digunakan guru cukup disukai siswa. Hal ini terlihat pada minat dan antusias siswa pada saat mengikuti pembelajaran. Berdasarkan hasil tes di akhir pembelajaran siklus I membuktikan bahwa dengan metode Cooperative Integrated Reading and Composition dan teknik Repetisi yang diperoleh mengalami peningkatan dari prasiklus. Hasil tes keterampilan membaca intensif secara klasikal sudah menunjukkan ketegori cukup baik dari tiap aspeknya. Namun, keterampilan siswa dalam membaca intensif perlu diperbaiki. Hal itu terlihat ketika proses membaca intensif, siswa masih melakukan hal-hal yang harus dihindari dalam membaca, seperti mengangkat teks bacaan, vokalisasi, membaca dengan menggerakkan kepala, dan kurang konsentrasi terhadap teks bacaan.

Untuk memperbaiki perilaku siswa agar lebih ke arah positif maka pada pengajaran membaca intensif untuk menemukan gagasan utama dengan metode Cooperative Integrated Reading and Composition dan teknik Repetisi siklus II nantinya akan direncanakan pembelajaran yang lebih matang. Pemberian reward bagi siswa yang mendapat nilai bagus. Penciptaan suasana yang lebih kondusif, proses pembelajaran yang lebih menarik dan menyenangkan. 


\section{Siklus II}

Hasil tes siklus I menunjukkan keterampilan membaca intensif untuk menemukan gagasan utama dengan menggunakan metode Cooperative Integrated Reading and Composition dan teknik Repetisi pada siswa kelas VII SMP Negeri 1 Suruh Trenggalek masih dalam kategori cukup dan belum memenuhi nilai target maksimal yang telah diterapkan. Selain itu, perubahan tingkah laku siswa masih belum menunjukkan perubahan yang berarti. Untuk itu, diperlukan tindakan siklus II untuk mengatasi masalah yang muncul dalam siklus I tersebut. Pembelajaran pada siklus II ini masih menggunakan metode Cooperative Integrated Reading and Composition dan teknik Repetisi, tetapi telah dilakukan perbaikan-perbaikan untuk mengatasi masalah-masalah yang ada pada siklus I. Berikut hasil tes dan nontes siklus II.

\section{1) Hasil Tes Siklus II}

Hasil tes pada siklus II diperoleh dari pelaksanaan tes membaca intensif untuk menemukan gagasan utama dan tes menyimpulkan isi teks bacaan dalam bentuk ringkasan dengan menerapkan metode Cooperative Integrated Reading and Composition dan teknik Repetisi.

Dalam pelaksanaan siklus II ini, sama dengan siklus I, tetapi yang membedakan adalah anggota kelompok tiap tim berbeda dari siklus I, dan teks bacaan yang digunakan juga berbeda dari siklus sebelumnya. Setelah itu, mereka berkelompok membaca teks bacaan berjudul "Kekayaan Hutan Mangrove di Papua". Dengan kelompok yang baru mereka juga saling menyumbangkan pendapat atau saran dalam menganalisis teks bacaan pada pengajaran membaca intensif untuk menemukan gagasan utama dengan menerapkan metode Cooperative Integrated Reading and Composition dan teknik Repetisi. Selanjutnya pada akhir pembelajaran guru memberikan tes membaca intensif untuk menemukan gagasan utama dan tes menyimpulkan isi dari teks bacaan dalam bentuk ringkasan. Hasil tes pada siklus II dapat dilihat sebagai berikut. Aspek menemukan gagasan utama dalam teks bacaan

Tabel 4. Hasil tes pada siklus II

\begin{tabular}{|c|c|c|c|c|c|c|}
\hline No & $\begin{array}{l}\text { Rentang } \\
\text { Nilai }\end{array}$ & Kategori & Frekuensi & Bobo & sentase & $\begin{array}{l}\text { Skor Rata- } \\
\text { rata }\end{array}$ \\
\hline 1 & $90-100$ & Sangat Baik & - & - & - & $=71,74$ \\
\hline 2 & $70-89$ & Baik & 26 & 1968 & $60 \%$ & Kategori \\
\hline 3 & $50-69$ & Cukup & 17 & 1117 & $40 \%$ & Baik \\
\hline 4 & $30-49$ & Kurang & - & - & - & \\
\hline 5 & $10-29$ & Sangat Kurang & - & - & - & \\
\hline \multicolumn{3}{|c|}{ Jumlah } & 43 & 3085 & $100 \%$ & \\
\hline
\end{tabular}

\section{2) Observasi}

Pada saat siklus II ini, observasi dilaksanakan pada saat proses pembelajaran berlangsung, sama dengan pelaksanaan pada siklus I. Berdasarkan data observasi yang dilakukan selama proses pengajaran membaca intensif untuk menemukan gagasan utama dengan menggunakan metode Cooperative Integrated Reading and Composition dan teknik Repetisi pada siklus II ini, guru merasakan adanya perubahan perilaku siswa. Hal ini dapat diketahui dari siswa yang sebelumnya tidak mengikuti kegiatan pembelajaran dengan baik, pada siklus II ini siswa mulai mengikuti dan melaksanakan kegiatan pembelajaran yang ditetapkan oleh guru. Bukti perubahan tingkah laku siswa dapat dilihat dari data observasi berikut ini. 
Vol 1. No 1. Juli 2021 e-ISSN : 2798-5733 P-ISSN : 2798-5741

Tabel 5. Hasil Observasi Siklus II

\begin{tabular}{|c|c|c|c|c|c|c|c|}
\hline \multirow[b]{2}{*}{ No } & \multirow[b]{2}{*}{ Aspek yang Diamati } & \multicolumn{3}{|c|}{ Melakukan } & \multicolumn{3}{|c|}{ Tidak Melakukan } \\
\hline & & $\mathrm{F}$ & $\%$ & K & $\mathrm{F}$ & $\%$ & K \\
\hline 1 & $\begin{array}{l}\text { Siswa semangat dan antusias saat } \\
\text { mengikuti pengajaran } \\
\text { keterampilan membaca intensif }\end{array}$ & 43 & $100 \%$ & SB & 0 & $0 \%$ & SK \\
\hline 2 & $\begin{array}{l}\text { Siswa merespon positif terhadap } \\
\text { metode Cooperative Integrated } \\
\text { Reading and Composition dan } \\
\text { teknik Repetisi yang digunakan } \\
\text { oleh guru }\end{array}$ & 33 & $77 \%$ & B & 10 & $23 \%$ & $\mathrm{~K}$ \\
\hline 3 & $\begin{array}{l}\text { Siswa membaca intensif dengan } \\
\text { sikap yang baik }\end{array}$ & 34 & $79 \%$ & B & 9 & $21 \%$ & $\mathrm{~K}$ \\
\hline 4 & $\begin{array}{l}\text { Kerjasama dalam kelompok } \\
\text { tinggi }\end{array}$ & 35 & $81 \%$ & SB & 8 & $19 \%$ & SK \\
\hline 5 & $\begin{array}{l}\text { Siswa aktif dan selalu bertanya } \\
\text { apabila mengalami kesulitan saat } \\
\text { membaca intensif dalam } \\
\text { menemukan gagasan utama }\end{array}$ & 33 & $77 \%$ & B & 10 & $23 \%$ & $\mathrm{~K}$ \\
\hline 6 & $\begin{array}{l}\text { Siswa memiliki sikap duduk dan } \\
\text { aktifitas yang baik }\end{array}$ & 35 & $81 \%$ & $\mathrm{SB}$ & 8 & $19 \%$ & SK \\
\hline 7 & $\begin{array}{l}\text { Siswa menerapkan metode } \\
\text { Cooperative Integrated Reading } \\
\text { and Composition dan teknik } \\
\text { Repetisi }\end{array}$ & 37 & $86 \%$ & SB & 6 & $14 \%$ & SK \\
\hline 8 & $\begin{array}{l}\text { Siswa mengerjakan tugas } \\
\text { membaca intensif teks bacaan }\end{array}$ & 43 & $100 \%$ & SB & 0 & $0 \%$ & SK \\
\hline & Jumlah rata-rata & 293 & $85 \%$ & & 51 & $15 \%$ & \\
\hline
\end{tabular}

Bukti perubahan tingkah laku siswa terlihat pada tabel 5 yang menyebutkan bahwa 43 siswa atau $100 \%$ siswa sudah benar-benar mengikuti kegiatan pembelajaran dengan baik. Dari data tersebut diketahui terjadi peningkatan sebesar $47 \%$ dari siklus I, sehingga dapat diketahui bahwa siswa sudah mampu menyesuaikan diri dengan penerapan kegiatan membaca intensif untuk menemukan gagasan utama dengan menggunakan metode Cooperative Integrated Reading and Composition dan teknik Repetisi. Siswa sudah nampak merespon positif dan antusias saat mengikuti pembelajaran pada siklus II. 


\section{3) Refleksi Siklus II}

Pada siklus II ini, refleksi dilakukan untuk mengetahui beberapa hal, yaitu (1) keefektifan penggunaan metode Cooperative Integrated Reading and Composition dan teknik Repetisi dalam kegiatan membaca intensif untuk menemukan gagasan utama teks bacaan; (2) untuk melihat peningkatan keterampilan membaca intensif untuk menemukan gagasan utama; dan (3) untuk mengetahui perilaku siswa setelah mengikuti kegiatan pengajaran membaca intensif untuk menemukan gagasan utama dengan menggunakan metode Cooperative Integrated Reading and Composition dan teknik Repetisi.

Pada pengajaran membaca intensif untuk menemukan gagasan utama dengan metode Cooperative Integrated Reading and Composition dan teknik Repetisi siklus II, siswa lebih antusias daripada siklus I. Siswa mulai tertarik dengan pembelajaran ini terutama pada saat menggunakan metode Cooperative Integrated Reading and Composition dan teknik Repetisi. Dengan metode Cooperative Integrated Reading and Composition dan teknik Repetisi, mereka dilatih untuk membaca dalam menemukan gagasan utama secara tepat. Dalam kegiatan membaca, kebiasaan buruk membaca mulai berkurang. Kesalahan tersebut seperti menyangga kepala, dan mengangkat teks bacaan.

Target yang ditetapkan pada siklus I, yaitu nilai rata-rata kelas keseluruhan setiap aspek sebesar 70 berhasil dicapai. Bahkan melebihi target, yaitu rata-rata nilai tes membaca siswa dalam menemukan gagasan utama sebesar 75,05 . Berarti terjadi peningkatan yang semula ditargetkan 70, namun rata-rata kelas mencapai 75,05 atau meningkat sebesar 8,24\% dari siklus I ke siklus II atau meningkat sebesar 15,58\% dari prasiklus ke siklus II. Dari hasil observasi, jurnal, wawancara, dan dokumentasi foto, tingkah laku siswa pada pembelajaran di siklus II lebih positif daripada siklus I walaupun masih ada siswa yang masih melakukan tingkah laku yang negatif, seperti mengganggu teman. Namun, pada siklus II ini pengajaran membaca intensif untuk menemukan gagasan utama dengan menggunakan metode Cooperative Integrated Reading and Composition dan teknik Repetisi sudah sesuai dengan target, maka penelitian mengenai peningkatan keterampilan membaca intensif untuk menemukan gagasan utama dengan menggunakan metode Cooperative Integrated Reading and Composition dan teknik Repetisi tidak dilanjutkan pada siklus selanjutnya.

\section{Pembahasan}

Berdasarkan dari data yang terkumpul, siswa yang memperoleh kategori skor sangat baik yang berada pada rentang nilai $85-100$ pada prasiklus dan siklus I belum ada, akan tetapi pada siklus II terdapat 1 orang siswa atau sebesar $2 \%$ dari jumlah keseluruhan siswa telah berhasil memperoleh kategori sangat baik. Adapun kategori skor baik yang memiliki rentang nilai 75-84 pada prasiklus ada 2 siswa atau sebesar 5\% . Pada tes akhir siklus I sebanyak 5 siswa atau sebesar $12 \%$ dan pada akhir siklus II sebanyak 26 siswa atau sebesar $61 \%$ telah memperoleh kategori baik. Kategori skor cukup yang berada pada rentang nilai 65-74 pada tes prasiklus sebesar 33\% atau 14 siswa, sedangkan pada tes akhir siklus I sebesar 49\% atau 21 siswa dan pada tes akhir siklus II sebesar $37 \%$ atau 16 orang siswa. Kategori skor kurang antara rentang nilai 55-64 pada kondisi awal atau prasiklus sebanyak 16 siswa atau 37\%, pada akhir tes siklus I yaitu sebesar 17 siswa atau sebesar 39\%, sedangkan pada akhir tes siklus II tidak ada siswa yang memperoleh nilai kategori skor kurang. Dan pada kategori sangat kurang yaitu rentang nilai $0-54$, pada kondisi awal atau prasiklus sebesar $25 \%$ atau sebanyak 11 siswa, pada akhir tes siklus I maupun siklus II tidak ada siswa yang memperoleh nilai kategori sangat kurang. Tetapi itu tidak merubah nilai rata-rata siswa yang dari prasiklus, siklus I, sampai siklus II terjadi peningkatan yang sangat baik pada siklus II sebesar $8,24 \%$ dari siklus I

Berdasarkan dari data yang terkumpul, siswa yang memperoleh kategori skor sangat baik yang berada pada rentang nilai $85-100$ pada prasiklus dan siklus I masih belum ada, akan tetapi pada siklus II sudah terdapat 1 orang siswa atau sebesar $2 \%$ dari jumlah keseluruhan 
siswa telah berhasil memperoleh kategori sangat baik. Adapun kategori skor baik, yang memiliki rentang nilai 75-84 pada prasiklus sebanyak 2 siswa atau sebesar 5\%. Pada tes akhir siklus I sebanyak 5 siswa atau sebesar 12\% dan pada akhir siklus II sebanyak 26 siswa atau sebesar $61 \%$ telah memperoleh kategori baik. Kategori skor cukup yang berada yang berada pada rentang nilai 65-74 pada tes prasiklus sebesar 33\% atau sebanyak 14 siswa, sedangkan pada akhir tes siklus I sebesar $49 \%$ atau sebesar 21 siswa dan pada tes akhir siklus II sebesar $37 \%$ atau sebesar 16 siswa. Kategori skor kurang antara rentang nilai 55-64 pada kondisi awal atau prasiklus sebanyak 16 siswa atau sebesar 37\%, pada akhir tes siklus I, yaitu sebesar 39\% atau sebanyak 17 siswa, sedangkan pada hasil tes siklus II tidak ada siswa yang memperoleh nilai kategori kurang. Dan pada kategori sangat kurang, yaitu antara rentang nilai 0-54 pada kondisi awal atau prasiklus sebesar $25 \%$ atau sebanyak 11 siswa, pada akhir tes siklus I maupun siklus II tidak ada siswa yang memperoleh nilai kategori sangat kurang. Walaupun terdapat peningkatan dari siklus I ke siklus II tetapi tidak mempengaruhi nilai rata-rata siswa pada prasiklus sampai siklus II mengalami peningkatan.

Peningkatan keterampilan membaca intensif untuk menemukan gagasan utama pada siswa merupakan sesuatu yang sangat menggembirakan bagi guru. Sebelum dilaksanakannya tindakan pada siklus I dan siklus II keterampilan membaca intensif terutama dalam menemukan gagasan utama dan menyimpulkan isi teks bacaan setelah dilakukannya tindakan pengajaran membaca intensif dengan menggunakan metode Cooperative Integrated Reading and Composition dan teknik Repetisi, keterampilan membaca intensif untuk menemukan gagasan utama mengalami peningkatan dari siklus I sampai dengan siklus II. Dengan demikian dapat disimpulkan bahwa penggunaan metode Cooperative Integrated Reading and Composition dan teknik Repetisi terbukti membantu siswa dalam meningkatkan keterampilan membaca intensif untuk menemukan gagasan utama serta menjadikan proses pembelajaran yang bermakna dan bermanfaat bagi siswa.

\section{KESIMPULAN}

Berdasarkan data-data, analisis, dan pembahasan dalam penelitian ini yang telah diuraikan pada bab sebelumnya, maka penulis mengambil simpulan sebagai berikut.

1. Keterampilan membaca intensif untuk menemukan gagasan utama dengan menggunakan metode Cooperative Integrated Reading and Composition dan teknik Repetisi telah terbukti mengalami peningkatan. Hasil tes keterampilan membaca intensif untuk menemukan gagasan utama pada prasiklus dapat diketahui nilai rata-rata sebesar 59,5 atau 59,47\% dan pada siklus I diperoleh nilai rata-rata sebesar 66,81 atau $66,81 \%$. Hal ini berarti terjadi peningkatan sebesar 7,34\%. Pada siklus II diperoleh nilai rata-rata kelas, tes menemukan gagasan utama sebesar 75,05 atau 75,05\%. Atas dasar hal tersebut dapat diketahui peningkatan dari siklus I ke siklus II sebesar 8,24\%. Hal ini juga dapat diketahui adanya peningkatan sebesar $15,58 \%$ dari prasiklus ke siklus II.

2. Perilaku siswa kelas VII SMP Negeri 1 Suruh Trenggalek tahun ajaran 2019/2020 setelah mengikuti pengajaran keterampilan membaca intensif untuk menemukan gagasan utama juga mengalami perubahan.

\section{DAFTAR PUSTAKA}

BSNP (Badan Standar Nasional Pendidikan). (2006). Standar Isi 2006 Mata Pelajaran Bahasa Indonesia untuk SMP/MTs. Jakarta.

Haryadi. (2006). Pokok-Pokok Keterampilan Membaca "Buku Ajar Mata Kuliah Keterampilan Membaca. Semarang: Universitas Negeri Semarang PKUPT Unnes/Pusat Penjamin Mutu dan Panitia Penulisan Buku Ajar/Buku Tes Unnes.

Haryadi. (2006). Retorika Membaca "Model, Metode, dan Teknik". Semarang: Rumah Indonesia. 
Munawaroh. (2005). Peningkatan Keterampilan Membaca Intensif Teks Profil Tokoh dengan Pendekatan Kontekstual Komponen Inquiry Pada Siswa Kelas VII SMP Negeri 10 Semarang Tahun Ajaran 2005/2006. Skripsi Mahasiswa Unnes.

Natalia. (2007). Peningkatan Keterampilan Membaca Pemahaman Melalui Media Komik Strips dengan Metode Cooperative Integrated Reading and Composition (CIRC) Pada Siswa Kelas III SD Negeri 02 Leyangan Grobogan. Skripsi Mahasiswa Unnes.

Nurhadi. (2005). Bagaimana Meningkatkan Kemampuan Membaca? "Suatu Teknik Memahami Literatur yang Efisien". Bandung: Sinar Baru Algensindo.

Nurhadi. (2005). Membaca Cepat dan Efektif. Bandung: Sinar Baru Algensindo. Rasiti. 2008. Peningkatan Keterampilan Membaca Tabel dengan Metode

Cooperative Integrated Reading and Composition (CIRC) Pada Siswa Kelas VII F SMP Negeri 6 Semarang Tahun Ajaran 2007/2008. Skripsi Mahasiswa Unnes.

Rejeki. (2001). Peningkatan Keterampilan Membaca Pemahaman dengan Menggunakan Teknik Close Pada Siswa Kelas II SLTP Negeri 1 Sukorejo Kendal Tahun Ajaran 2000/2001. Skripsi Mahasiswa Unnes.

Sanjaya, Wina. (2008). Strategi Pembelajaran "Berorientasi Standar Proses Pendidikan". Jakarta: Kencana Prenada Media Group.

Slavin, Robert E. (2008). Cooperative Lerning "Teori, Riset, dan Praktik. Bandung: Nusa Media.

Somad, Adi Abdul, dkk. (2008). Aktif dan Kreatif Berbahasa Indonesia untuk Kelas X SMA/MA (Teks Bacaan "Kekayaan Hutan Mangrove di Papua” dan Teks Bacaan "Mengenal Penyakit Flu Burung”). Jakarta: Pusat Perbukuan Departemen Pendidikan Nasional.

Subyakto, dkk. (2004). Materi Pelatihan Terintegrasi 3 "Bahasa Indonesia”. Jakarta: Departemen Pendidikan Nasional, Direktorat Pendidikan Lanjutan Pertama.

Subyantoro. (2007). Penelitian Tindakan Kelas. Semarang: Rumah Indonesia.

Suhendar M.E, Supinah Pien. (1993). Efektifitas Metode Pengajaran Bahasa Indonesia. Bandung: Pionir Jaya.

Susanip. (2006). Peningkatan Keterampilan Membaca Ekstensif Beberapa Berita yang Bertopik Sama dengan Pendekatan Kontekstual Komponen Inquiry pada Kelas VIII C SMP Negeri 1 Tarub Kabupaten Tegal Tahun Ajaran 2005/2006. Skripsi Mahasiswa Unnes. Suyatno. (2004). Teknik Pembelajaran Bahasa dan Sastra. Surabaya: SIC.

Tarigan, Henry Guntur. (1979). Membaca Sebagai Suatu Keterampilan Berbahasa. Bandung: Angkasa.

Tarigan, Henry Guntur, dkk. (1990). Membaca dalam Kehidupan. Bandung: Angkasa.

Tim Edukatif. (2007). Kompeten Berbahasa Indonesia untuk SMA Kelas X (Teks Bacaan "Pengembangan Iptek Tidak Bisa Liar"). Jakarta: Erlangga.

Wagiran, Doyin Mukh. (2005). Curah Gagasan Pengantar Penulisan Karya Ilmiah. Semarang: Rumah Indonesia. 